\title{
Cytomorphological characteristics of glassy cell carcinoma of the uterine cervix: histopathological correlation and human papillomavirus genotyping
}

\author{
Yoon Yang Jung ${ }^{1}$, Ji Hae Nahm ${ }^{2}$, Hyun-Soo Kim ${ }^{3}$ \\ ${ }^{1}$ Department of Pathology, Myongji Hospital, Seonam University College of Medicine, Goyang-si, Republic of Korea \\ ${ }^{2}$ Department of Pathology, Asan Medical Center, University of Ulsan College of Medicine, Seoul, Republic of Korea \\ ${ }^{3}$ Department of Pathology, Severance Hospital, Yonsei University College of Medicine, Seoul, Republic of Korea \\ Correspondence to: Hyun-Soo Kim, email: hyunsookim@yuhs.ac
}

Keywords: cervix, glassy cell carcinoma, cytology, human papillomavirus

Received: August 02, 2016

Accepted: September 17, 2016

Published: September 30, 2016

\section{ABSTRACT}

A retrospective analysis was performed to describe the cytomorphological and histopathological findings and human papillomavirus (HPV) genotypes for glassy cell carcinoma (GCC) of the uterine cervix. Five cases of cervical GCC, in which the glassy cell features constituted at least $\mathbf{9 5 \%}$ of the specimen, were included. Four patients had stage IIB GCCs and one had stage IIIB GCC. All patients underwent concurrent chemoradiation therapy. Based on pretreatment cytology, only 1 of the 5 cases was correctly diagnosed as GCC. The remaining cases were diagnosed as carcinoma of undetermined type, adenocarcinoma, poorly differentiated carcinoma, or unsatisfactory for evaluation. Cytological specimens had moderate cellularity and contained small clusters of tumor cells admixed with amphophilic, granular tumor diathesis. The tumor cells possessed large, round to oval nuclei and abundant, granular, groundglass cytoplasm. The nuclei exhibited prominent eosinophilic nucleoli. The cytoplasm displayed sharp margins and molding, resulting in "intercellular windows" between neighboring attached cells. HPV genotyping revealed that high-risk HPV types 18, 16, and 31 were detected in 3, 1, and 1 cases, respectively. Consistent with this finding, all cases exhibited block p16 positivity, confirming the association of HPV infection with GCC. In conclusion, a distinct cytoplasmic margin, the characteristic histopathological feature of GCC, was observed in liquid-based cytological preparations. We suggest that sharp cytoplasmic outlines with molding and intercellular windows are characteristic cytomorphological features of GCC. Detection of high-risk HPV in all cases strongly supported the notion that high-risk HPV is involved in the pathogenesis of GCC.

\section{INTRODUCTION}

Glassy cell carcinoma (GCC) of the uterine cervix is a rare pathological form of cervical carcinoma that occurs in $1-2 \%$ of all cases [1-3]. The World Health Organization Classification currently considers this tumor to be a subtype of "other epithelial tumors" [4]. The mean patient age of those with GCC is $\sim 10$ years less than that of patients with squamous cell carcinoma or adenocarcinoma of the cervix $[1,2,5]$. GCC was first described by Cherry and Glucksmann [6] in 1956 as a specific and distinctive entity of the most poorly differentiated adenosquamous carcinoma. They defined the histological diagnostic criteria and indicated that this tumor was uncommon and associated with poor prognosis. Two decades later, Littman et al. [2] described GCC tumors in detail, redefining and amplifying the histological criteria. Since then, interest in GCC has expanded and a number of studies have been conducted $[1-3,7-22]$. However, cervical GCC is not yet widely recognized. Furthermore, because of GCC rarity there have been no clinical trials or large cohort studies.

Early detection of cervical cancer greatly increases the successful treatment rate. In countries with established early detection programs, the impact of cytology-based cervical screening is reflected in the substantial reduction in the cervical cancer incidence over the past 50 years 
[23-27]. Although the aggressive clinical course of GCC encourages the use of early detection methods because data on the cytological features of GCC are limited, a cytological diagnosis can be difficult, despite characteristic histopathological features $[1-4,17]$. Liquid-based cytology can improve specimen quality by providing a standardized method of collecting cervicovaginal material, and dispersing cells in a thin layer that is relatively inflammation-free [28-30]. This reduces the likelihood of unsatisfactory smears and increases the cytomorphological abnormality detection rate [31-37]. Although liquid-based cytology has become a common screening method for cervical cancer, limited information is available on the liquid-based cytology findings of GCC.

The aim of the present study was to describe the cytomorphological and histopathological features and immunophenotypes of cervical GCC. In addition, human papillomavirus (HPV) infection status in cervical GCCs was evaluated. We found characteristic cytomorphological features, and verified that those are consistent with typical histopathological features of GCC. We observed high-risk HPV infection and block p16 positivity in all examined cases.

\section{RESULTS}

\section{Patient demographics}

During the period from July 2007 to June 2016, 675 patients were diagnosed as having primary cervical carcinoma. Thirty-three $(4.9 \%)$ cases of poorly differentiated carcinoma were collected from computerized patient records. Based on the rarity of GCC, we reviewed the $9(1.3 \%)$ cases of cervical poorly differentiated adenosquamous carcinoma. Among the 9 cases, 2 cases that presented glassy cell features but that also had squamous ( 1 case) or glandular (1 case) differentiation, and 2 cases that had diffuse, strong p 40 expression were excluded. The remaining $5(0.7 \%)$ cases were cervical GCCs. Five patients with cervical GCC were included in a retrospective analysis. The median and mean patients ages at diagnosis were 38 and 48.2 years, respectively (range, $36-67$ years). Four $(80.0 \%)$ of the 5 patients had International Federation of Gynecology and Obstetrics (FIGO) stage IIB GCCs and the remaining 1 $(20.0 \%)$ had FIGO stage IIIB GCC. None of the patients were pregnant or had a recent history of pregnancy. All patients underwent concurrent chemoradiation therapy.

\section{Cytological findings}

The clinicopathological characteristics of the 5 patients with cervical GCC are summarized in Table 1. Based on pretreatment cytology, only $1(20.0 \%)$ of the 5 cases was correctly diagnosed as GCC (case 4), although for the case with an unsatisfactory cytological specimen on the first examination, a cytological diagnosis of GCC was obtained from the recurrent tumor (case 3). The remaining cases were diagnosed as carcinoma, type undetermined (case 1), adenocarcinoma (case 2), or poorly differentiated carcinoma (case 5). There were no false negative results. Liquid-based cytology specimens displayed moderate cellularity and contained small clusters of polygonal tumor cells admixed with amphophilic, granular necrotic debris (tumor diathesis; Figure 1A). Most cellular clusters had $<20$ cells. Even though most tumor cells were cohesive, individual tumor cells were frequently observed. A background of tumor diathesis was common (Figure 1B). Some tumor cells assumed a pseudocolumnar shape, resembling endocervical cells (Figure 1C), but there was no definitive evidence of glandular differentiation. Rarely, cellular clusters showing vague acinar architecture and nuclear polarization were noted, but insufficient for diagnosis of adenocarcinoma. There was no evidence of dyskeratosis or intercellular bridge formation. The tumor cells possessed large, round to oval nuclei with a thin, irregular nuclear membrane. Although most tumor cells had finely dispersed chromatin, some had coarse chromatin and thick nuclear membranes with dense parachromatin. A moderate to large amount of tumor cell cytoplasm stained faintly blue with Papanicolaou stain, giving a fine ground-glass appearance (Figure 1D). The cytoplasm displayed distinct outlines with molding and clear, slit-like spaces between neighboring attached cells ("intercellular windows"; Figure 1E). The tumor cells were 3-7 fold larger than lymphocytes, and the majority of their nuclei contained prominent nucleoli (Figure 1F). Occasionally, tumor cell phagocytosis of apoptotic neutrophils was observed. There was a mixed population of inflammatory cells, mainly plasma cells and lymphocytes, in the background. Eosinophils, though present, were not easily detected. An intimate admixture of neutrophils and tumor cells, a so-called granuloepithelial complex [13], was often identified (Figures 1G-1I). Cytoplasmic molding and intercellular windows were often seen in these complexes. Frequent mitoses (Figures $1 \mathrm{~J}-1 \mathrm{~K}$ ) and atypical mitotic figures (Figures $1 \mathrm{~L}$ ) were detected.

\section{Histopathological and immunohistochemical findings}

Histopathologically, the tumor tissue consisted of nests, cords, or sheets of large polygonal cells with a moderate to large amount of pale, evenly spread, finely granular or ground glass-appearing cytoplasm (Figure 2A). The tumor cell nests were separated by thin, delicate fibrovascular septa, containing a cellular infiltrate, which consisted predominantly of plasma cells and lymphocytes admixed with eosinophils (Figure 2B). The individual tumor cells exhibited sharp cytoplasmic outlines and large, pleomorphic nuclei with prominent 
Table 1: Results of cytology, biopsy, immunostaining, and HPV genotyping and treatment of cervical GCC

\begin{tabular}{|c|c|c|c|c|c|c|c|c|c|c|c|}
\hline \multirow[t]{2}{*}{ Case } & \multirow[t]{2}{*}{ Age } & \multirow{2}{*}{$\begin{array}{l}\text { FIGO } \\
\text { stage }\end{array}$} & \multirow[t]{2}{*}{ Cytology result } & \multirow{2}{*}{$\begin{array}{c}\text { Biopsy } \\
\text { result }\end{array}$} & \multicolumn{5}{|c|}{ Immunostaining result } & \multirow{2}{*}{$\begin{array}{c}\text { HPV } \\
\text { genotype }\end{array}$} & \multirow[t]{2}{*}{ Treatment } \\
\hline & & & & & p40 & CEA & ER & PgR & p16 & & \\
\hline 1 & 38 & IIB & $\begin{array}{c}\text { Carcinoma, type } \\
\text { undetermined }\end{array}$ & GCC & Negative & Negative & Negative & Negative & $\begin{array}{c}\text { Block } \\
\text { positive }\end{array}$ & $\begin{array}{l}\text { HR HPV } \\
\text { (type 18) } \\
\text { detected }\end{array}$ & CCRT \\
\hline 2 & 63 & IIB & Adenocarcinoma & $\mathrm{GCC}$ & Negative & Negative & Negative & Negative & $\begin{array}{c}\text { Block } \\
\text { positive }\end{array}$ & $\begin{array}{l}\text { HR HPV } \\
\text { (type 16) } \\
\text { detected }\end{array}$ & CCRT \\
\hline 3 & 36 & IIB & $\begin{array}{l}\text { Unsatisfactory/ } \\
\text { GCC* }\end{array}$ & $\mathrm{GCC}$ & Negative & Negative & Negative & Negative & $\begin{array}{c}\text { Block } \\
\text { positive }\end{array}$ & $\begin{array}{l}\text { HR HPV } \\
\text { (type } 31 \text { ) } \\
\text { detected }\end{array}$ & CCRT \\
\hline 4 & 67 & IIIB & $\mathrm{GCC}$ & $\mathrm{GCC}$ & Negative & Negative & Negative & Negative & $\begin{array}{l}\text { Block } \\
\text { positive }\end{array}$ & $\begin{array}{l}\text { HR HPV } \\
\text { (type 18) } \\
\text { detected }\end{array}$ & CCRT \\
\hline 5 & 37 & IIB & $\begin{array}{c}\text { Poorly } \\
\text { differentiated } \\
\text { carcinoma }\end{array}$ & $\mathrm{GCC}$ & Negative & Negative & $\begin{array}{c}\text { Focal } \\
\text { positive }\end{array}$ & $\begin{array}{c}\text { Focal } \\
\text { positive }\end{array}$ & $\begin{array}{c}\text { Block } \\
\text { positive }\end{array}$ & $\begin{array}{l}\text { HR HPV } \\
\text { (type 18) } \\
\text { detected }\end{array}$ & CCRT \\
\hline
\end{tabular}

Abbreviations: CCRT: concurrent chemoradiation therapy, CEA: carcinoembryonic antigen, ER: estrogen receptor; FIGO: International Federation of Gynecology and Obstetrics, GCC: glassy cell carcinoma, HPV: human papillomavirus, HR: high-risk, PgR: progesterone receptor; *At the time of recurrence

nucleoli (Figure 2C). Mitotic figures were numerous and included abnormal forms (Figure 2D). Under highpower magnification $(\times 400)$, the distinct cytoplasmic margins that were seen on the cytological specimens were often observed. Cell shape variation associated with cytoplasmic molding and intercellular windows was consistent with that found on the cytology (Figures 2E-2F). Some tumor cells displayed cytoplasmic microvacuolation. Bizarre multinucleated giant cells were commonly seen (Figure 2G). There was no evidence of squamous pearl formation, dyskeratosis, or intercellular bridge formation. Although a pseudocolumnar arrangement of the tumor cells that was observed on the cytological specimens was also found (Figure 2H), there was no evidence of gland formation or mucin production. A few microscopic foci of coagulative tumor cell necrosis were present.

Immunohistochemical staining results are shown in Table 1. Estrogen (ER; Figure 2I) and progesterone (PgR; Figure $2 \mathrm{~J}$ ) receptors were focally positive in 1 case. None of the cases showed p40 (Figure $2 \mathrm{~K}$ ) or carcinoembryonic antigen (CEA; Figure 2L) expression. In contrast, all cases exhibited diffuse and strong nuclear and cytoplasmic p16 immunoreactivity (block positivity; Figure 2M).

\section{HPV genotype status}

HPV genotype was analyzed using HPV DNA chip assay. High-risk HPV was detected in all cases (Table 1). This result was in agreement with the block p16 positivity observed in all cases. The genotype was variable; type 18 was detected in three $(60.0 \%)$ cases, and type $16(20.0 \%)$ and type $31(20.0 \%)$ was detected in 1 case for each. Multiple HPV genotypes were not observed.

\section{DISCUSSION}

It has been documented that GCC does not have a distinctive cytological appearance [2, 3, 17]. In the present study, a pretreatment cytological diagnosis of GCC was made in only 1 case examined. Similar to our observation, in a previous study, 1 of 9 (11.1\%) GCC cases were correctly diagnosed on a cervicovaginal smear [13]. The remaining cases were diagnosed as squamous cell carcinoma (3 cases), adenocarcinoma (1 case), adenosquamous carcinoma (1 case), or carcinoma, unknown type (3 cases). The reason for such a low diagnostic accuracy in cytology might be attributed to the lack of differentiation and a low suspicion index for GCC. However, pathologists should be aware of the cytomorphological features of GCC because it not only has relatively unique cytomorphology but also diagnostic pitfalls, leading to occasional misdiagnosis. In our series, the established histopathological findings of GCC were verified in the cytological specimens. Clusters of tumor cells with abundant, granular cytoplasm, pleomorphic nuclei, and prominent nucleoli were consistent with GCC histomorphology. In addition, sharp cytoplasmic outlines of GCC cells associated with cytoplasmic molding 
and intercellular window formation were apparent in liquid-based cytological preparations, and these were confirmed on histopathological examination. Although sharp cytoplasmic margins have been suggested as a histopathological characteristic of GCC, there have been no reports concerning cytoplasmic molding and intercellular windows as cytomorphological features. Since these 2 features are typically found in reactive or
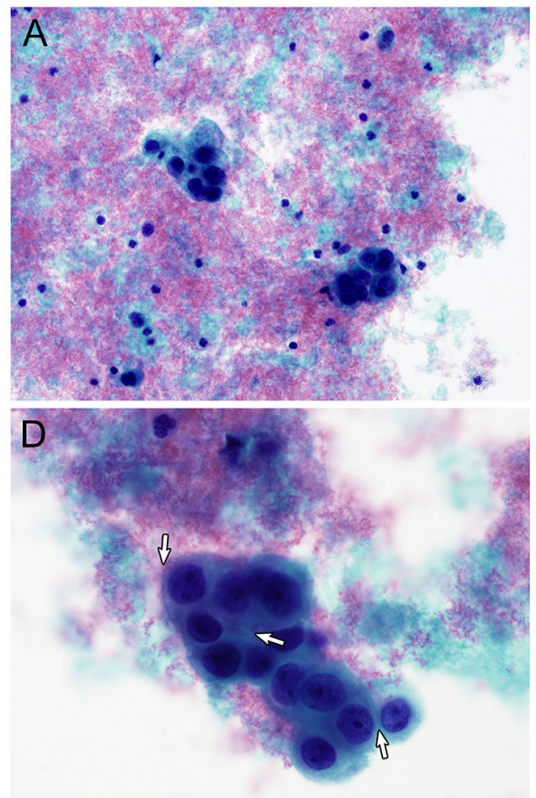

G
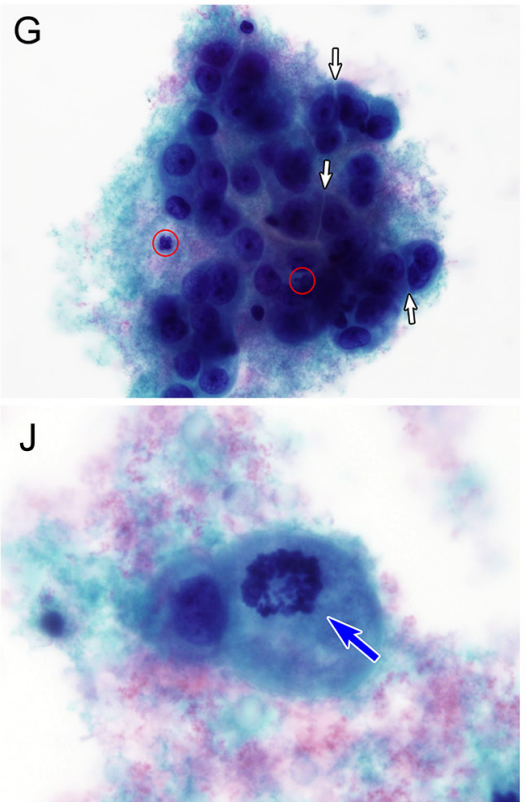

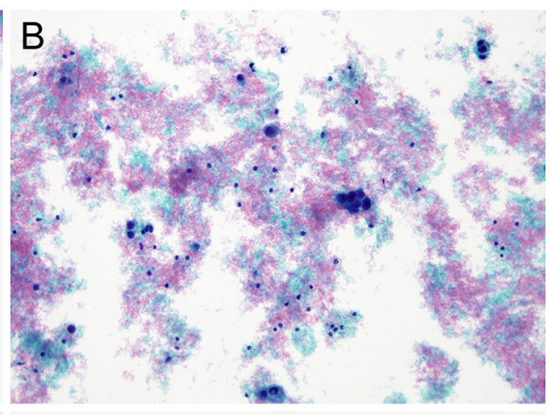

$\mathrm{E}$

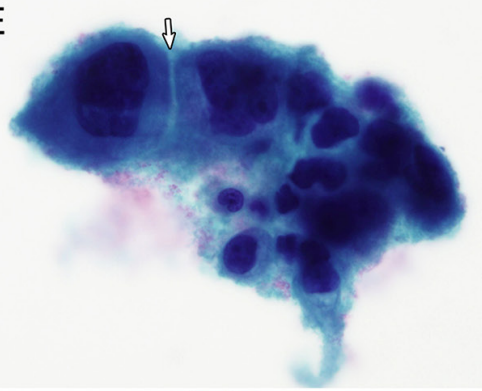

$\mathrm{H}$
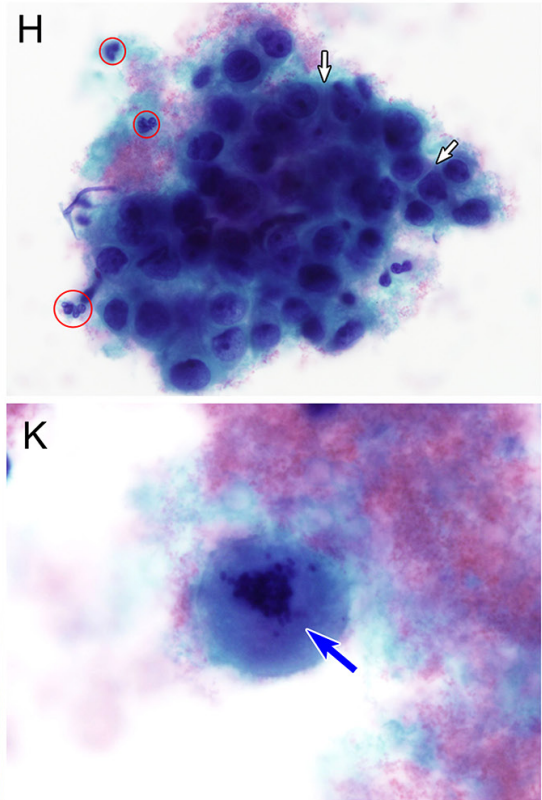

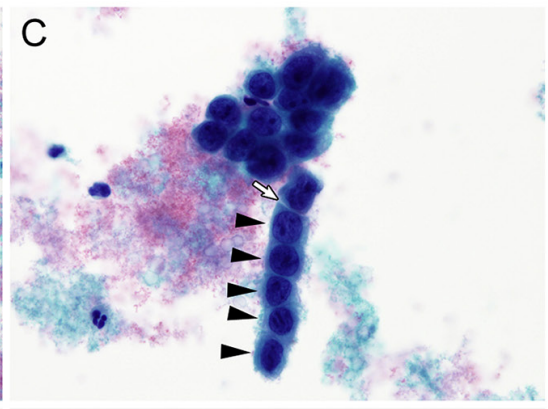

$\mathrm{F}$

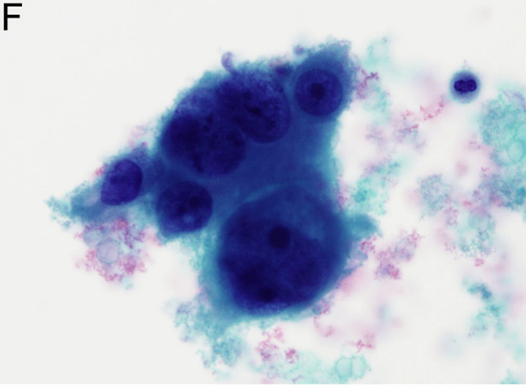

I
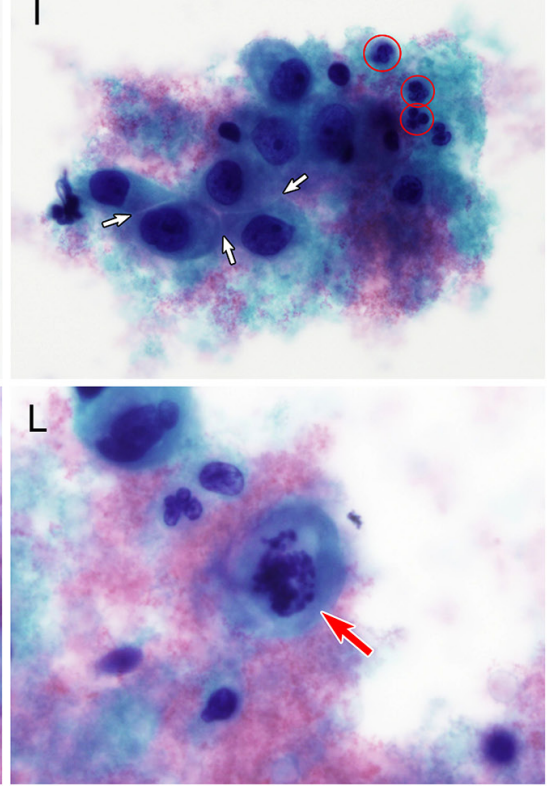

Figure 1: Liquid-based cytological findings of cervical glassy cell carcinoma. A. Thinprep preparation of the cervical sample shows amphophilic, granular necrotic debris (tumor diathesis) and a few small clusters of polygonal tumor cells. B. The tumor cell clusters or individually scattered tumor cells are unevenly distributed. Tumor diathesis is apparent. C. Although some tumor cells display endocervical-like pseudocolumnar arrangements (black arrowheads), there is no definite evidence of glandular differentiation. A white arrow indicates the intercellular window. D. The tumor cells have relatively fine chromatin and prominent, solitary nucleoli. Abundant, cyanophilic cytoplasm and discrete cell borders (white arrows) are evident. E. Under high-power magnification $(\times 400)$, the tumor cells show large, oval to round, pleomorphic nuclei and "intercellular windows" produced by discrete cytoplasmic outlines and cytoplasmic molding (white arrow). There are no intercellular bridges. F. Tumor cells are 3-7 fold larger than lymphocytes or neutrophils. Chromatin distribution irregularities, hyperchromasia, and significant anisonucleosis are apparent. G-I. In several areas, an intimate admixture of neutrophils (red circles) and tumor cells, so-called granuloepithelial complexes, is seen. Cytoplasmic molding and intercellular windows (white arrows) are observed. J-K. Mitotic figures (blue arrows) are present. L. Atypical mitotic figures (red arrow) are also detected (A-L, Papanicolaou stain). 
neoplastic mesothelial lesions, it is difficult to conclude that they are pathognomonic for cervical GCC. However, because cytoplasmic molding and intercellular windows are not found in liquid-based cytology of common cervical neoplastic lesions such as high-grade squamous intraepithelial lesion, squamous cell carcinoma, adenocarcinoma in situ, and endocervical adenocarcinoma, it could be inferred that at least cytoplasmic molding and

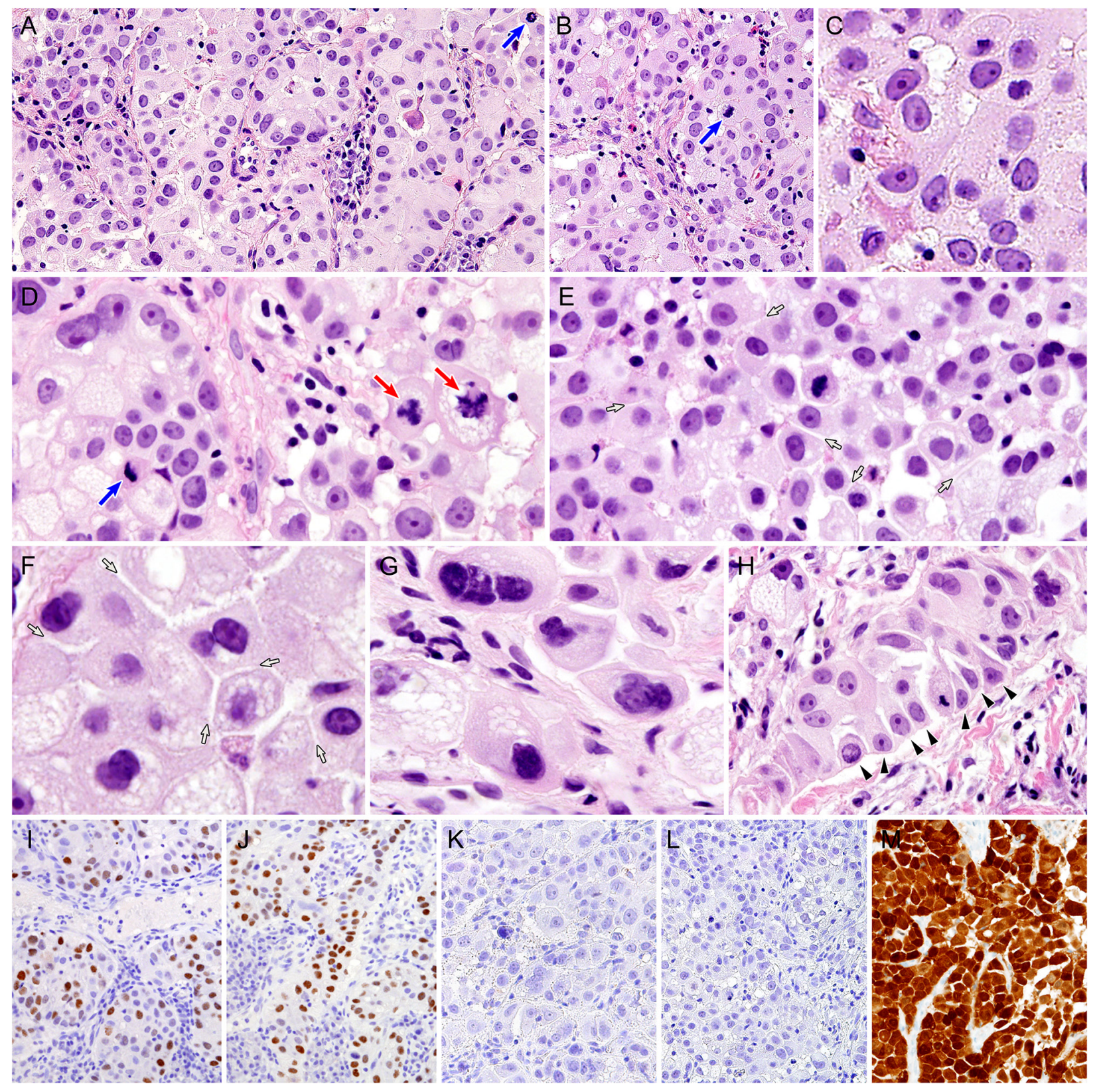

Figure 2: Histopathological and immunohistochemical findings of cervical glassy cell carcinoma. A. Glassy cell carcinoma consists of tumor cell nests with pale to eosinophilic, abundant cytoplasm. Mitotic figures are frequently observed (blue arrow). B. The tumor cell nests are surrounded by thin fibrovascular connective tissue septa with lymphoplasmacytic infiltrate. A blue arrow indicates a mitotic figure within the tumor cell. C. The individual tumor cells display large nuclei with single, prominent nucleoli. D. Tumor cell cytoplasm possesses eosinophilic, granular cytoplasm, and some exhibit variable-sized microvacuoles. In several areas, mitotic figures are frequent (blue arrow), including abnormal forms (red arrows). E. The tumor cells show distinct cytoplasmic margins and "intercellular windows" (white arrows), which are also apparent in cytological specimens. F. Under high-power magnification $(\times 400)$, cytoplasmic molding and clear, slit-like intercellular spaces (white arrows) are obviously observed, but intercellular bridging is absent. G. Some bizarre multinucleated giant cells are noted. H. Although cells with a pseudocolumnar arrangement can be seen (black arrowheads), there is no definite evidence of gland formation. I-M. Immunohistochemically, some tumor cells are positive for (I) estrogen receptor and (J) progesterone receptor in a single case. None of the cases examined shows immunoreactivity for (K) p40 or (L) carcinoembryonic antigen. In contrast, all cases exhibited block positivity for (M) p16 (A-H, hematoxylin and eosin stain; I-M, polymer method). 
distinct intercellular windows could be useful cytological features to diagnose GCC.

Previous studies have found a strong association between cervical GCC and high-risk HPV infection [3, 7-12], which would be consistent with the findings in the present study. According to an accumulation of the present and previous data, the overall prevalence of high-risk HPV infection would be $51.3 \%$ (20/39; Table 2). Interestingly, 3 previous cases showed multiple high- and low-risk HPV infections [12], whereas in the present study high-risk HPV alone was noted. In the present study, 3 (60.0\%) cases had HPV type 18, which was the most common type detected in previous studies $(10 / 15 ; 75.0 \%)$. HPV type 18 is most commonly associated with glandular tumors of the uterine cervix $[4,7,8]$, which leads to the argument that GCC should be identified as a subtype of adenocarcinoma rather than of squamous cell carcinoma; however, the GCC glandular lineage cannot be proven because HPV type 18 is not specific to glandular lesions. In fact, HPV type 18 is the second most common HPV types in cervical squamous epithelial lesions and is strongly associated with high-grade neuroendocrine carcinomas [38]. Therefore, it is reasonable to assume that HPV type 18 has an ability to make a target cell differentiate in variable directions [8]. Although the pathogenetic importance of high-risk HPV infection in cervical GCC could not be determined definitively because of the small number of cases reported, based on the results of the present and previous studies there is a high possibility that it is involved in GCC carcinogenesis. Further studies are needed for a full evaluation of HPV infection status in GCC of the uterine cervix.

In the present study, all the five cases we examined expressed block p16 positivity, which was consistent with the presence of high-risk HPV. In addition, focal ER and PgR positivity in 1 case was consistent with a previous study that detected ER (2 cases) and PgR (1 case) among 11 cases of GCC [16]. However, considering that the remaining 4 cases were negative for both $\mathrm{ER}$ and $\mathrm{PgR}$, and most cervical carcinomas does not express these hormone receptors, their expression may be unusual in GCC.

Cytological differential diagnoses of cervical GCC include atypical reparative cells, nonkeratinizing squamous cell carcinoma with severe inflammation, lymphoepithelioma-like carcinoma, and malignant melanoma. Pak et al. [17] reported a false-negative rate of $33 \%$ when performing a cytological diagnosis of GCC. In GCC, frequently appearing syncytial tumor cell arrangements and abundant cytoplasm may deceive cytopathologists. In typical repair, cells occur primarily in monolayer sheets and syncytia and contain prominent nucleoli. However, nuclear piling, significant

Table 2: Previously reported HPV prevalence rate and genotypes in cervical GCC

\begin{tabular}{|c|c|c|c|c|c|}
\hline \multirow{2}{*}{$\begin{array}{l}\text { Year } \\
\text { published }\end{array}$} & \multirow[t]{2}{*}{ Author } & \multirow{2}{*}{$\begin{array}{c}\text { HPV } \\
\text { prevalence rate }\end{array}$} & \multicolumn{3}{|c|}{ HPV genotype } \\
\hline & & & Category & Type (number of case) & $\begin{array}{c}\text { Detection } \\
\text { method }\end{array}$ \\
\hline 1998 & Kenny et al. [7] & $27.8 \%(5 / 18)$ & HR & $18(4), 16(1)$ & ISH \\
\hline 2002 & Kato et al. [8] & $66.7 \%(2 / 3)$ & HR & $18(2)$ & PCR \\
\hline 2004 & Hirai et al. [9] & $100.0 \%(2 / 2)$ & HR & $18(2)$ & PCR \\
\hline 2004 & Ng et al. [10] & $0.0 \%(0 / 1)$ & Not detected & & PCR-RFLP \\
\hline 2004 & $\begin{array}{c}\text { Matthews-Greer et al. } \\
{[11]}\end{array}$ & $100.0 \%(1 / 1)$ & HR & $16(1)$ & PCR \\
\hline 2009 & Kim et al. [12] & $55.6 \%(5 / 9)$ & HR and LR & $\begin{array}{c}18(2), 31+32(1) \\
35+68+32(1), 39+6(1)\end{array}$ & DNA chip \\
\hline 2016 & Jung et al.* & $100.0 \%(5 / 5)$ & $\mathrm{HR}$ & $18(3), 16(1), 31(1)$ & DNA chip \\
\hline \multirow[t]{2}{*}{$1998-2016$} & Total & $51.3 \%(20 / 39)$ & HR & $\begin{array}{c}18(65.0 \% ; 13 / 20), \\
16(15.0 \% ; 3 / 20), \\
31(10.0 \% ; 2 / 20), \\
35(5.0 \% ; 1 / 20), \\
39(5.0 \% ; 1 / 20), \\
68(5.0 \% ; 1 / 20)\end{array}$ & \\
\hline & & & LR & $\begin{array}{c}32(10.0 \% ; 2 / 20), \\
6(5.0 \% ; 1 / 20)\end{array}$ & \\
\hline
\end{tabular}

Abbreviations: HPV: human papillomavirus, HR: high-risk, ISH: in situ hybridization, LR: low-risk, PCR: polymerase chain reaction, PCR-RFLP: polymerase chain reaction-restriction fragment length pleomorphism assay; *The present study 
anisonucleosis, and irregularities in chromatin distribution that exceed changes in typical repair, can result in the false exclusion of carcinoma. Nevertheless, atypical reparative reactions lack both tumor diathesis and nuclear hyperchromasia. Moreover, isolated atypical tumor cells in reparative reactions are uncommon [13]. Compared with nonkeratinizing squamous cell carcinoma with inflammation, GCC tumor cells are larger and more polygonal with larger nuclei and distinct cell membranes. Nonkeratinizing squamous cell carcinoma has more oval nuclei with coarser chromatin, which is frequent distributed along the nuclear membrane. In lymphoepithelial-like carcinoma, cell membranes are indistinct, and the nuclear chromatin is distributed peripherally, marginating the nuclear membrane. Although eosinophils are often observed in GCC, in lymphoepithelial-like carcinoma the majority of infiltrating inflammatory cells are lymphocytes and plasma cells, which might be useful for differentiation. However, it is not clear if there is a significant difference in proportion of the inflammatory cells between these 2 diseases because in the present cases, lymphoplasmacytic infiltrates were dominant. A misdiagnosis of malignant melanoma might be avoided by the absence of cytoplasmic melanin pigments and epithelial marker immunoreactivity. GCC neither expresses HMB-45 nor Melan A.

In conclusion, we have described the cytomorphology, histopathology, immunophenotype, and HPV genotypes of cervical GCC. We demonstrated that distinct cytoplasmic margins are a major cytomorphological and histopathological feature of GCC. Cytoplasmic molding and intercellular window formation might be useful cytomorphological characteristics for a differential diagnosis of GCC, especially in liquid-based preparations. In addition, high-risk HPV infection in all cases supported the notion that high-risk HPV is involved in the pathogenesis of GCC.

\section{MATERIALS AND METHODS}

\section{Case selection}

Glassy cell features were defined based on the 3 main criteria originally reported by Cherry and Glucksmann [6] and amplified by Littman et al. [2] as: (1) cells with a moderate amount of ground-glass or finely granular cytoplasm that stains faintly blue with hematoxylin and eosin, (2) distinct cytoplasmic borders that stain with eosin and periodic acidSchiff, and (3) large nuclei with conspicuous nucleoli. The present study was restricted to cases in which the glassy cell features constituted at least $95 \%$ of the specimen. All available slides of 9 poorly differentiated adenosquamous carcinoma cases were reviewed. Five cases of cervical GCCs were included in the present study. Pretreatment cytological specimens were available for all 5 cases. The present study was reviewed and approved by the Institutional Review Board of Severance Hospital, Yonsei University Health System, Seoul, Republic of Korea (2016-1010-001).

\section{Liquid-based cytological specimen preparation}

For liquid-based cytological smears, samples were taken from the fornix, portio, and endocervix. The ThinPrep test (Hologic Inc., Marlborough, MA, USA) was performed using an automated liquid-based monolayer cell preparation system (ThinPrep 2000 system; Hologic Inc.), according to manufacturer's recommendations. Briefly, the samples were immersed in CytoLyt buffer (Hologic Inc.) and then transferred to a PreservCyt bowl (Hologic Inc.). Cells were released by pushing the brush to the bottom, forcing the bristles apart, and swirling the brush in the fluid. A cylinder containing a filtration membrane was placed in the bowl and rotated to ensure homogeneous cell distribution. Erythrocytes and mucus were allowed to penetrate the filtration membrane under negative pressure, leaving the cell membranes on the filtration membrane. Each ThinPrep slide was fixed in ethanol and stained using the Papanicolaou method. Tumor diathesis, cellular composition, and cellular arrangement of the specimens were evaluated.

\section{Histopathological examination}

The biopsied specimens were fixed in 10\% neutralbuffered formalin and embedded in paraffin blocks. From each formalin-fixed, paraffin-embedded block, 4- $\mu \mathrm{m}$ sections were cut and stained with hematoxylin and eosin. A variable number of hematoxylin and eosin-stained slides from each case were available for review. Among these, the most representative slide, containing an appropriate volume of tumor and possibly normal cervical tissue, was chosen for immunohistochemical staining and HPV genotyping.

\section{Immunohistochemistry}

The formalin-fixed, paraffin-embedded sections were deparaffinized and rehydrated using xylene and alcohol. Immunohistochemical staining was performed using the Ventana Benchmark XT automated staining system (Ventana Medical Systems, Tucson, AZ, USA) or the Dako Omnis (Dako, Agilent Technologies, Carpinteria, CA, USA), according to the manufacturer's instructions. Antigen retrieval was performed using Cell Conditioning Solution (CC1; Ventana Medical Systems) or EnVision FLEX Target Retrieval Solution, High pH (Dako, Agilent Technologies). Sections were incubated with primary antibodies (Table 3). After chromogenic visualization, using ultraView Universal DAB Detection Kits (Ventana Medical Systems) or EnVision FLEX /HRP (Dako, Agilent Technologies), slides were counterstained with hematoxylin. Appropriate positive and negative controls were stained concurrently to validate the staining method. 
Table 3: Antibodies used for immunohistochemical staining

\begin{tabular}{lccc}
\hline Antibody & Source & Clone & Dilution \\
\hline $\begin{array}{l}\text { Carcinoembryonic } \\
\text { antigen }\end{array}$ & Dako, Agilent Technologies Inc., Carpinteria, & II-7 & $1: 400$ \\
Estrogen receptor & CA, USA & SP1 & $1: 100$ \\
Progesterone receptor & Dako, Agilent Technologies Inc., Carpinteria, & PgR 636 & $1: 50$ \\
CA, USA & CSA & E6H4 & Prediluted \\
p40 & Ventana Medical Systems, Tucson, AZ, USA & Polyclonal & $1: 200$ \\
\hline
\end{tabular}

\section{Human papillomavirus genotyping}

We performed polymerase chain reaction (PCR)-based microarray for HPV genotyping, using a commercially available HPV 9G DNA chip (BMT HPV 9G DNA Chip; Biometrix Technology, Chuncheon, Republic of Korea) [39]. The $9 \mathrm{G}$ test examined the presence of 14 high-risk $(16,18,31,33,35,39,45,51$, $52,56,58,59,66,68)$ and 5 low-risk $(6,11,34,40$, 42) HPV types; analyses were performed according to the manufacturer's instructions [40]. Briefly, the PCR mixture consisted of $10 \mu \mathrm{L}$ of the extracted target DNA, $10 \mu \mathrm{L}$ of the primer set (provided by the manufacturer), and PCR premix (provided by the manufacturer), which contained dNTP and Taq DNA polymerase in an amplification buffer. Amplification was performed using the following steps: predenaturation for $5 \mathrm{~min}$ at $94^{\circ} \mathrm{C} ; 40$, 30-s denaturation cycles at $94^{\circ} \mathrm{C} ; 40,30-\mathrm{s}$ annealing cycles at $45^{\circ} \mathrm{C} ; 40,30$-s elongation cycles at $72^{\circ} \mathrm{C}$; and a final 5 -min elongation step at $72^{\circ} \mathrm{C}$. PCR products were electrophoresed in a $2 \%$ agarose gel to confirm successful amplification. Each hybridization chamber of the $9 \mathrm{G}$ was covered with a mixture of the hybridization solution $(35 \mu \mathrm{L})$ and PCR product (15 $\mu \mathrm{L})$, followed by incubation at $23-26^{\circ} \mathrm{C}$ for $30 \mathrm{~min}$. After washing, array images were scanned and imaged using a fluorescent scanner (ScanArray GX Microarray Scanner, PerkinElmer Life and Analytical Sciences, Waltham, MA, USA).

\section{ACKNOWLEDGMENTS}

This study was supported by a faculty research grant of Yonsei University College of Medicine for 2016 (6-2016-0130).

\section{CONFLICTS OF INTEREST}

The authors declare that they have no conflicts of interest.

\section{REFERENCES}

1. Gray HJ, Garcia R, Tamimi HK, Koh WJ, Goff BA, Greer $\mathrm{BE}$ and Paley PJ. Glassy cell carcinoma of the cervix revisited. Gynecol Oncol. 2002; 85: 274-277.

2. Littman P, Clement PB, Henriksen B, Wang CC, Robboy SJ, Taft PD, Ulfelder H and Scully RE. Glassy cell carcinoma of the cervix. Cancer. 1976; 37: 2238-2246.

3. Zolciak-Siwinska A and Jonska-Gmyrek J. Glassy cell carcinoma of the cervix: a literature review. Eur J Obstet Gynecol Reprod Biol. 2014; 179: 232-235.

4. Kurman RJ, Carcangiu ML, Herrington CS and Young RH. WHO Classification of Tumours of Female Reproductive Organs. Lyon: International Agency for Research on Cancer; 2014.

5. Lotocki RJ, Krepart GV, Paraskevas M, Vadas G, Heywood $\mathrm{M}$ and Fung FK. Glassy cell carcinoma of the cervix: a bimodal treatment strategy. Gynecol Oncol. 1992; 44: 254-259.

6. Cherry CP and Glucksmann A. Incidence, histology, and response to radiation of mixed carcinomas (adenoacanthomas) of the uterine cervix. Cancer. 1956; 9: 971-979.

7. Kenny MB, Unger ER, Chenggis ML and Costa MJ. In situ hybridization for human papillomavirus DNA in uterine adenosquamous carcinoma with glassy cell features ("glassy cell carcinoma"). Am J Clin Pathol. 1992; 98: 180-187.

8. Kato N, Katayama Y, Kaimori M and Motoyama T. Glassy cell carcinoma of the uterine cervix: histochemical, immunohistochemical, and molecular genetic observations. Int J Gynecol Pathol. 2002; 21: 134-140.

9. Hirai Y, Kawamata Y, Takeshima N, Furuta R, Kitagawa T, Kawaguchi T, Hasumi K, Sugai S and Noda T. Conventional and array-based comparative genomic hybridization analyses of novel cell lines harboring HPV18 from glassy cell carcinoma of the uterine cervix. Int J Oncol. 2004; 24: 977-986.

10. Ng WK, Cheung LK and Li AS. Liquid-based cytology findings of glassy cell carcinoma of the cervix. Report of a case with histologic correlation and molecular analysis. Acta Cytol. 2004; 48: 99-106. 
11. Matthews-Greer J, Dominguez-Malagon H, Herrera GA, Unger J, Chanona-Vilchis J, Caldito G and TurbatHerrera EA. Human papillomavirus typing of rare cervical carcinomas. Arch Pathol Lab Med. 2004; 128: 553-556.

12. Kim SK, Shim HS, Lee KG, An HJ, Lee KR and Cho NH. Glassy cell carcinoma predominantly commits to a squamous lineage and is strongly associated with high-risk type human papillomavirus infection. Int J Gynecol Pathol. 2009; 28: 389-395.

13. Chung JH, Koh JS, Lee SS and Cho KJ. Glassy cell carcinoma of the uterine cervix. Cytologic features and expression of estrogen and progesterone receptors. Acta Cytol. 2000; 44: 551-556.

14. Costa MJ, Kenny MB, Hewan-Lowe K and Judd R. Glassy cell features in adenosquamous carcinoma of the uterine cervix. Histologic, ultrastructural, immunohistochemical, and clinical findings. Am J Clin Pathol. 1991; 96: 520-528.

15. Hopkins MP and Morley GW. Glassy cell adenocarcinoma of the uterine cervix. Am J Obstet Gynecol. 2004; 190: $67-70$.

16. Kuroda H, Toyozumi Y, Masuda T, Ougida T, Hanami K, Kyoko K, Tamaru J and Itoyama S. Glassy cell carcinoma of the cervix: cytologic features and expression of estrogen receptor, progesterone receptor and Her $2 /$ neu protein. Acta Cytol. 2006; 50: 418-422.

17. Pak HY, Yokota SB, Paladugu RR and Agliozzo CM. Glassy cell carcinoma of the cervix. Cytologic and clinicopathologic analysis. Cancer. 1983; 52: 307-312.

18. Piura B, Rabinovich A, Meirovitz $M$ and Yanai-Inbar I. Glassy cell carcinoma of the uterine cervix. J Surg Oncol. 1999; 72: 206-210.

19. Reis-Filho JS, Fillus Neto J, Schonemann E, Sanderson A and Schmitt FC. Glassy cell carcinoma of the uterine cervix. Report of a case with cytohistologic and immunohistochemical study. Acta Cytol. 2001; 45: 407-410.

20. Takekuma M, Hirashima Y, Takahashi N, Yamamichi G, Furukawa N, Yamada Y, Takakuwa R and Ito I. A case of glassy cell carcinoma of the uterine cervix that responded to neoadjuvant chemotherapy with paclitaxel and carboplatin. Anticancer Drugs. 2006; 17: 715-718.

21. Talerman A, Alenghat E and Okagaki T. Glassy cell carcinoma of the uterine cervix. APMIS Suppl. 1991; 23: 119-125.

22. Deshpande AH, Kotwal MN and Bobhate SK. Glassy cell carcinoma of the uterine cervix a rare histology. Report of three cases with a review of the literature. Indian J Cancer. 2004; 41: 92-95.

23. Arbyn M, Raifu AO, Weiderpass E, Bray F and Anttila A. Trends of cervical cancer mortality in the member states of the European Union. Eur J Cancer. 2009; 45: 2640-2648.

24. de Kok IM, van der Aa MA, van Ballegooijen M, Siesling S, Karim-Kos HE, van Kemenade FJ and Coebergh JW. Trends in cervical cancer in the Netherlands until 2007: has the bottom been reached? Int J Cancer. 2010; 128: 2174-2181.
25. Dijkstra MG, Snijders PJ, Arbyn M, Rijkaart DC, Berkhof $\mathrm{J}$ and Meijer CJ. Cervical cancer screening: on the way to a shift from cytology to full molecular screening. Ann Oncol. 2014; 25: 927-935.

26. Gustafsson L, Ponten J, Zack $M$ and Adami HO. International incidence rates of invasive cervical cancer after introduction of cytological screening. Cancer Causes Control. 1997; 8: 755-763.

27. Peto J, Gilham C, Fletcher O and Matthews FE. The cervical cancer epidemic that screening has prevented in the UK. Lancet. 2004; 364: 249-256.

28. Austin RM and Ramzy I. Increased detection of epithelial cell abnormalities by liquid-based gynecologic cytology preparations. A review of accumulated data. Acta Cytol. 1998; 42: 178-184.

29. Mount S, Harmon M, Eltabbakh G, Uyar D and Leiman G. False positive diagnosis in conventional and liquid-based cervical specimens. Acta Cytol. 2004; 48: 363-371.

30. Vassilakos P, Carrel S, Petignat P, Boulvain M and Campana A. Use of automated primary screening on liquid-based, thin-layer preparations. Acta Cytol. 2002; 46: 291-295.

31. Beckwith DG, Shane JJ and Dupree WB. The promise and risk of a new technology: the Lehigh Valley Hospital's experience with liquid-based cervical cytology. Cancer. 1998; 84: 317-318.

32. Bolick DR and Hellman DJ. Laboratory implementation and efficacy assessment of the ThinPrep cervical cancer screening system. Acta Cytol. 1998; 42: 209-213.

33. Diaz-Rosario LA and Kabawat SE. Performance of a fluidbased, thin-layer papanicolaou smear method in the clinical setting of an independent laboratory and an outpatient screening population in New England. Arch Pathol Lab Med. 1999; 123: 817-821.

34. Dupree WB, Suprun HZ, Beckwith DG, Shane JJ and Lucente V. The promise and risk of a new technology: The Lehigh Valley Hospital's experience with liquid-based cervical cytology. Cancer. 1998; 84: 202-207.

35. Fremont-Smith M, Marino J, Griffin B, Spencer L and Bolick D. Comparison of the SurePath liquid-based Papanicolaou smear with the conventional Papanicolaou smear in a multisite direct-to-vial study. Cancer. 2004; 102 : 269-279.

36. Papillo JL, Zarka MA and St John TL. Evaluation of the ThinPrep Pap test in clinical practice. A seven-month, 16,314-case experience in northern Vermont. Acta Cytol. 1998; 42: 203-208.

37. Roberts JM, Gurley AM, Thurloe JK, Bowditch R and Laverty CR. Evaluation of the ThinPrep Pap test as an adjunct to the conventional Pap smear. Med J Aust. 1997; 167: 466-469.

38. Stoler MH, Mills SE, Gersell DJ and Walker AN. Smallcell neuroendocrine carcinoma of the cervix. A human papillomavirus type 18-associated cancer. Am J Surg Pathol. 1991; 15: 28-32. 
39. Bae GE, Yoon G, Song YJ and Kim HS. High-grade squamous intraepithelial lesion arising adjacent to vulvar lymphangioma circumscriptum: a tertiary institutional experience. Oncotarget. 2016; 7: 48120-48129. doi: 10.18632/oncotarget.10158.
40. An H, Song KS, Nimse SB, Kim J, Nguyen VT, Ta VT, Sayyed DR and Kim T. HPV 9G DNA chip: 100\% clinical sensitivity and specificity. J Clin Microbiol. 2012; 50: 562-568. 